\title{
Champion of the free press
}

\section{BY MARY-LOUISE O'CALLAGHAN}

STRING thirty three coral atolls together and you have Kiribati, one of the smallest countries in the world. Scatter these scratches of coral across an area of the Pacific Ocean equivalent to the United States of America, and you start to comprehend the immutable obstacles facing this precarious little nation's existence just north of the equator.

It is here, in Kiribati's splendid isolation that you will find Ieremia Tabai, a man who has done more than most to advance not just his people's quest for a better life but all the Pacific island states. These days the Pacific elder statesman, clad in a $t$-shirt and shorts, can usually be found inside a modest concrete block building about 100 metres from the sea, helping to put out possibly the smallest national newspaper in the world - the Kiribati Newstar; circulation 1700.

With a cover price of 60 cents, the Newstar hits the street (there is only one road in the capital, Tarawa) on Friday mornings, its national distribution achieved when Tabai and his wife, Meleangi, stop off at the South Tarawa post office on their way home from a night of folding and inserting the A4sized paper, to post copies to the outer islands.

One of three media projects Tabai has set up this, year - a Newstar website and FM radio station, New Air, are close to being launched production of this little newspaper - Kiribati's first independent media outlet - is surrounded by an air of excitement and enthusiasm akin to fording a new frontier.

"Until now all the media in Kiribati has been controlled by the Government," Tabai said a recent interview. "The [Government] paper and the radio will never put out anything critical of the Government. If they do, it is by accident." he says with a laugh.

Kiribati's first president following independence in 1979, Tabai's steady 12 -year stewardship of the former British colony, the Gilbert Islands, is widely credited with keeping the tiny nation on the right side of viable. Especially significant was his careful management of a trust fund established by the British in 1956 with royalties from phosphate mining which $œ$ Continued overleaf 


\section{CHAMPION OF THE FREE PRESS}

\section{$œ$ From previous page}

has given the island nation a head start compared with most of its cashstarved neighbours. Now worth $\$ 630$ million, the fund is equivalent to an incredible 10 years import cover for the 90,000 odd people of Kiribati even though they are heavily dependent upon imports.

Following his second term as President, Tabai became the South Pacific's chief bureaucrat for six years, retiring in 1997 after two terms as Secretary-General of the region's peak political body, the Pacific Islands Forum. A post at the United Nations, Commonwealth Secretariat or another major international organisation seemed the inevitable next step in such a career, but instead Tabai returned home to contest and secure a seat in Kiribati's national Parliament.

No longer interested in serving in Government, Tabai says becoming co-owner-publisher of the Newstar is a logical development of a lifetime of service to the public, rather than a departure from it.

"When I entered government first in 1978, I believed it was bad for the state to monopolise the news - it probably had to do with my exposure to New Zealand," says Tabai who was educated at Wellington's Victoria University.

"The first thing I did when I got into government as chief minister, was to make the broadcasting unit, which then was just a division of the ministry, a statutory body. Later when I was working in Fiji [at the Forum Secretariat] and as I travelled around, it was al ways in the back of my mind that one day it would be possible to have an independent media here because I have a basic belief that you can't have democracy without it."

Tabai's partners in his media ventures include his brother and a Melbourne based I-Kiribati woman, Siau Smith, who between them have managed to keep Newstar's start-up and the installation of a state-of-the-art FM studio debt free. It's a fact that's helping to keep the company afloat despite the recent withdrawal of most Government advertising.

"I am on the wrong side of politics," Tabai, officially a member of the Opposition, says abruptly." My initial plan was to have the radio up and ready in time before the last general election in 1998...but they applied the $\rightarrow$ Continued on page 18 


\section{CHAMPION OF THE FREE PRESS \\ Cofrom page 16}

law in such a way that it would delay the whole thing. If the government was going to use the state radio for their news then other people could use ours and they realized that of course.

"When I recognised that it was going to take us a while to get it started, I said OK, let's get the newspaper going."

Published in Kiribati vernacular, Newstar is modest in its efforts, offering up a mix of local and foreign news. Taking as its lead story in the week the Pacific Island Forum came to town, the annual regional heads of government meeting, followed on page two with a good-old fashioned police rounds story about a man knifed over a land boundary dispute. The. paper also sports a joke eolumn, crossword and a features page which this particular week profiled a well-known local composer.

But Tabai is anxious for the paper to go much further.

"My only regret so far, is that we have not done any stories like the Peter Reith [phone card controversy] story in Australia, I think in time we will cover more interesting stories. Right now we need more experiencedreporters.

"What we can say, is that we have already had an impact on the Government paper, they are working much harder too, generally things they would not accept there, we will run, like letters complaining about Government."

Tabai brushes his hands across a dozen or so foreign newspapers and magazines spread across a bench.

From the front page of one Sydney tabloid, Peter Reith screams: "IAM NOT A LIAR". Alongside it Fiji's Daily Post declares allegations of corruption against a Government now deposed.

"This is my collection, but people keep borrowing them," Tabai says ruefully.

"Putting out a newspaper, is something I really love to do. I've been in government, I've worked in the region, but for me, I believe this will be my major contribution to my country, it really is as important as that." $\square$ 